OCCASIONAL PAPER

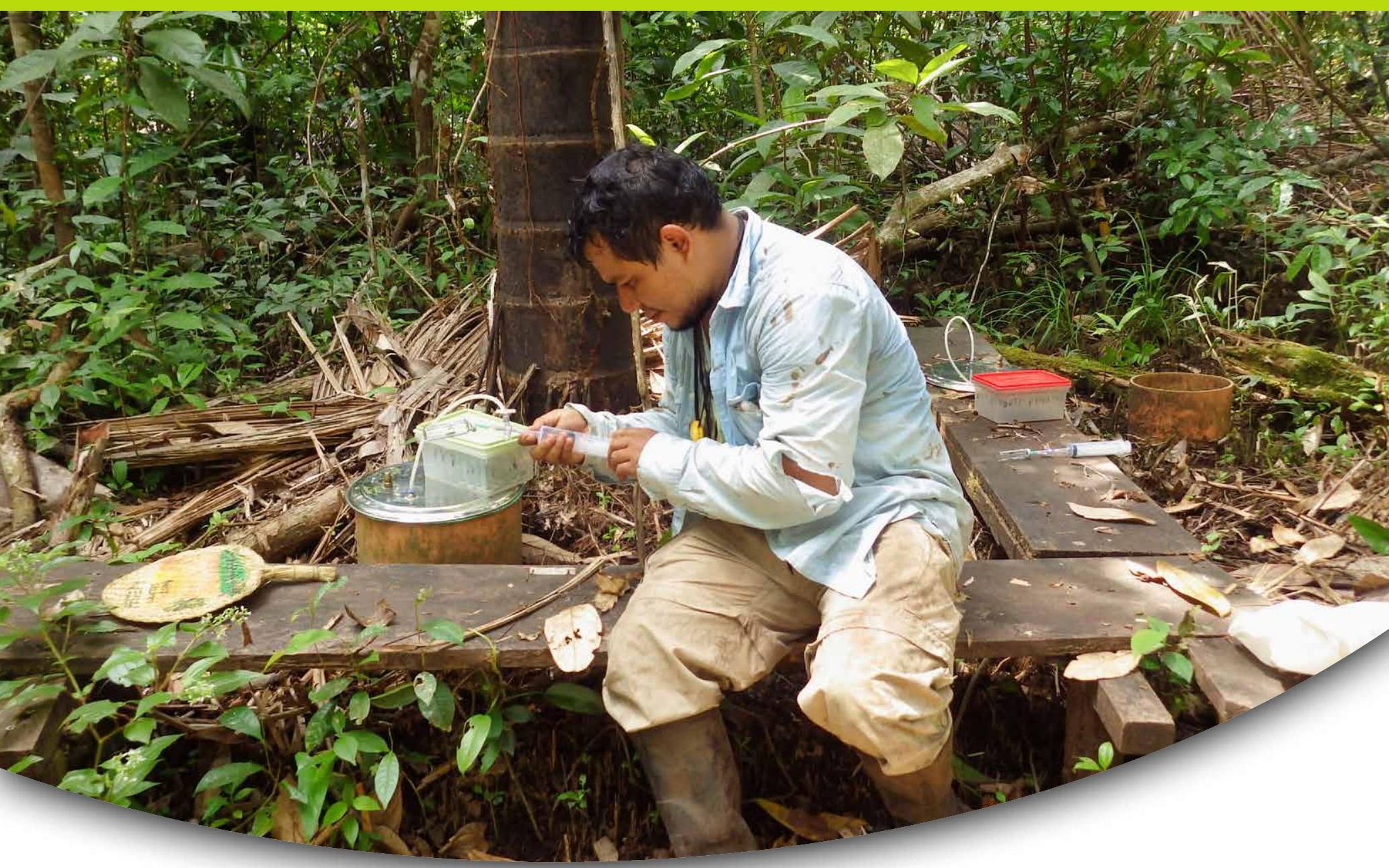

\title{
What do we know about Peruvian peatlands?
}

Mariela López Gonzales

Kristell Hergoualc'h

Óscar Angulo Núñez

Timothy Baker

Rodney Chimner

Jhon del Águila Pasquel

Dennis del Castillo Torres
Luis Freitas Alvarado

Beatriz Fuentealba Durand

Erick García Gonzales

Eurídice Honorio Coronado

Hirose Kazuyo

Erik Lilleskov

Natalia Málaga Durán
Mónica Maldonado Fonkén

Manuel Martín Brañas

Tony Mori Vargas

Ana María Planas Clarke

Katherine Roucoux

Faustino Vacalla Ochoa
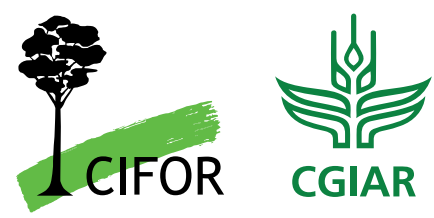



\section{What do we know about Peruvian peatlands?}

Mariela López Gonzales

Center for International Forestry Research (CIFOR)

Kristell Hergoualc'h

Center for International Forestry Research (CIFOR)

\section{Óscar Angulo Núñez}

Institute of Natural Sciences, Territory and Renewable Energy at the Catholic University of Peru (INTE-PUCP)

\section{Timothy Baker}

University of Leeds

\section{Rodney Chimner}

School of Forest Resources and Environmental Science, Michigan Technological University

\section{Jhon del Águila Pasquel}

Institute for Research of the Peruvian Amazon (IIAP)

\section{Dennis del Castillo Torres}

Institute for Research of the Peruvian Amazon (IIAP)

Luis Freitas Alvarado

Institute for Research of the Peruvian Amazon (IIAP)

\section{Beatriz Fuentealba Durand}

Department for Mountain Ecosystems, National Institute for Research on Glaciers and Mountain Ecosystems (INAIGEM)

\section{Erick García Gonzales}

Department of Quality and Evaluation of Water Resources, National Water Authority (ANA)

\author{
Eurídice Honorio Coronado \\ Institute for Research of the Peruvian Amazon (IIAP) \\ Hirose Kazuyo \\ Japan Space Systems \\ Erik Lilleskov \\ USDA Forest Service, Northern Research Station \\ Natalia Málaga Durán \\ Center for International Forestry Research (CIFOR)
}

\section{Mónica Maldonado Fonkén}

Plant Ecology, Center for Ornithology and Biodiversity (CORBIDI)

Manuel Martín Brañas

Institute for Research of the Peruvian Amazon (IIAP)

\section{Tony Mori Vargas}

Regional Environmental Authority, Regional Government of Loreto (ARA-GOREL)

\section{Ana María Planas Clarke \\ SilvaCarbon}

Katherine Roucoux

University of St Andrews

\section{Faustino Vacalla Ochoa}

SERFOR-CAF Forestry Program of the National Forestry and Wildlife Service (SERFOR) 
Occasional Paper 210

() 2020 Center for International Forestry Research (CIFOR)

Content in this publication is licensed under a Creative Commons Attribution 4.0 International (CC BY 4.0), http://creativecommons.org/licenses/by/4.0/

ISBN 978-602-387-142-1

DOI: $10.17528 /$ cifor/007848

López Gonzales M, Hergoualc'h K, Angulo Núñez Ó, Baker T, Chimner R, del Águila Pasquel J, del Castillo Torres D, Freitas Alvarado L, Fuentealba Durand B, García Gonzales E et al. 2020. What do we know about Peruvian peatlands? Occasional Paper 210. Bogor, Indonesia: CIFOR.

Translation of López Gonzales M, Hergoualc'h K, Angulo Núñez Ó, Baker T, Chimner R, del Águila Pasquel J, del Castillo Torres D, Freitas Alvarado L, Fuentealba Durand B, García Gonzales E et al. 2020. ¿Qué sabemos sobre las turberas peruanas? Documentos Ocasionales 208. Bogor, Indonesia: CIFOR.

Contributors: José Álvarez Alonso (Department of Biological Diversity, Ministry of the Environment (MINAM)); Janet Calvo Vargas (Department of Biological Diversity, MINAM); Claudia Enrique Fernández (Department for Sustainable Conservation of Ecosystems and Species, MINAM); Walter Huamaní (Department of Biological Diversity, Ministry of the Environment, MINAM); and Tatiana Pequeño Saco (Department for Monitoring and Evaluation of Natural Resources of the Territory, MINAM).

Photo by Kristell Hergoualc'h/CIFOR

Greenhouse gases sampling in palm swamp forest of the Peruvian Amazon (Quistococha Regional Reserve, Loreto-Peru).

\author{
CIFOR \\ Jl. CIFOR, Situ Gede \\ Bogor Barat 16115 \\ Indonesia \\ $\mathrm{T}+62(251) 8622-622$ \\ $F+62(251) 8622-100$ \\ E cifor@cgiar.org
}

\title{
cifor.org
}

We would like to thank all funding partners who supported this research through their contributions to theCGIAR Fund. For a full list of the 'CGIAR Fund' funding partners please see: http://www.cgiar.org/our-funders/

Any views expressed in this publication are those of the authors. They do not necessarily represent the views of CIFOR, the editors, the authors' institutions, the financial sponsors or the reviewers 


\section{Contents}

Acknowledgments $\quad$ iv

1 Introduction 1

2 State of knowledge on Peruvian peatlands 2

2.1 Importance of Peruvian peatlands 2

2.2 Threats 5

$\begin{array}{lll}2.3 & \text { Regulatory framework } & 7\end{array}$

3 Opportunities and challenges $\quad 8$

$\begin{array}{lll}4 & \text { Recommendations } & 11\end{array}$

$\begin{array}{ll}\text { References } & 12\end{array}$

\section{List of figure and tables}

Tables

1 Estimated area of peatlands and ecosystems with the potential to form peat, by region 2

2 Main causes of peatland degradation in Peru 5

Scientific research required for the protection and sustainable management of
Peruvian peatlands

Figure

1 Ecosystems in Peru with the potential to form peat 3 


\section{Acknowledgments}

This research was conducted under the Sustainable Wetlands Adaptation and Mitigation Program (SWAMP) and the CIFOR Global Comparative Study on REDD+ (GCS-REDD+). It was generously supported by the governments of the United States of America (Grant MTO069018) and Norway (Grant \# QZA-12/0882). It was carried out as part of the CGIAR research program on Forests, Trees and Agroforestry (CRPFTA) with financial support from CGIAR Fund Donors. The authors are extremely grateful to all participants of the workshop on progress and challenges for the sustainable management of palm swamp peatlands in the Amazon (Iquitos, October 2018) and the national symposium on the sustainable management of Peruvian peatlands (Lima, April 2019) for their valuable contributions. This publication has been peerreviewed, and we thank Rodolfo Iturraspe, Veronica Pancotto, Juan Carlos Benavides, Christopher Martius and Peter Cronkleton for their reviews and suggestions. 


\section{Introduction}

Peatlands are wetlands where oxygen deficiency, caused by the high water table level, enables the slow decomposition of dead vegetation in situ and, consequently, the formation of peat. Peat soils are distinguished from mineral soils by their high carbon (C) content and a thick layer of partially decomposed organic material - that is peat - up to several meters deep. Although peatlands only occupy $2.8 \%$ of the Earth's surface (Xu et al. 2018), it is estimated that they store up to 850 gigatons $\left(1 \mathrm{Gt}=10^{15} \mathrm{~g}\right.$ ) of $\mathrm{C}$ in the soil (Yu e al. 2012; Gumbricht et al. 2017) which, is more than four times the $\mathrm{C}$ reserves of the aboveground vegetation in the tropics (188 Gt C, Avitabile et al. 2015). Due to the important role peatlands play in fixing and storing $\mathrm{C}$, their conservation, sustainable management and restoration are considered key climate change nature-based solutions, so as to reach the Paris Agreement goal of maintaining global warming below $2^{\circ} \mathrm{C}$ (Griscom et al. 2017). Peatlands are also essential for adaptation to climate change, through their provision of waterrelated ecosystem services like water storage and regulation, flood mitigation, and water purification at local and regional levels. Peatlands are also the habitat of unique biodiversity and perform important economic and cultural functions for human wellbeing. They are, however, very fragile ecosystems that have developed over thousands of years since the last ice age, and their degradation causes irreparable losses and disproportionately high greenhouse gas (GHG) emissions (Gaveau et al. 2014; Hergoualc'h et al. 2018).

The largest areas of tropical peatlands are found in Indonesia, the Congo Basin and the Amazon Basin (Gumbricht et al. 2017). For decades, the peat swamp forests of Southeast Asia (Indonesia and Malaysia) have suffered massive destruction mainly due to changes in land use to favor agricultural crops or plantations, which typically involve draining the peatland as an initial activity. It is estimated that $50 \%$ of these forests were lost between 1990 and 2010 (Miettinen et al. 2012). By contrast, the Peruvian peatlands are less degraded than those of Southeast Asia (Draper et al. 2014) but they could meet a similar fate if the lessons of other countries are not heeded (Lilleskov et al. 2017). It is essential, therefore, for Peruvian policies to ensure the conservation and sustainable use of peatlands, and prioritize them on the national climate and environmental agenda. At international level, various initiatives recognize the importance of peatlands and promote their rational use. Among them, the Ramsar Convention, which Peru acceded to in 1992, urges its contracting Parties to prioritize their peatlands (Ramsar 2002). Among its activities to support Parties, the Ramsar Convention provides a guide for inventories of tropical peatlands (Ramsar 2018). There is also the Global Peatland Initiative (GPI) whose objective is to assess the status and sustainable management of peatlands, their importance in local and national economies, and the fundamental role they play in global climate change mitigation objectives. Peru has also been invited to be part of the International Tropical Peatlands Center (ITPC), an initiative led by Indonesia and partnered with peatland-rich tropical countries, like the Democratic Republic of the Congo and the Republic of the Congo.

This publication aims to summarize current knowledge on Peruvian peatlands, emphasizing the threats that endanger their conservation, and highlighting both the challenges they face and opportunities for their sustainable management. 


\section{State of knowledge on Peruvian peatlands}

\subsection{Importance of Peruvian peatlands}

According to recent studies, Peru is one of the richest peatland countries in the tropics (Gumbricht et al. 2017). Its peatlands are distributed throughout the Amazon, Andean and coastal regions, with a significant extent in the Amazon, according to existing maps (Gumbricht et al. 2017; Chimner et al. 2019) and areas of ecosystem identified as having peat-forming potential (Table 1, Figure 1). Over three quarters of the Amazon peatlands are found in the North, in the department of Loreto (Gumbricht et al. 2017). In the Andes, most of the peatlands are located at over 3,800 m (Chimner et al. 2019). To date, Peru does not have a national peatlands inventory to enable a precise measurement of its total peatlands area.

The Amazon peatlands, locally known as chupaderas or sucking swamps, are home to three main kinds of ecosystems according to Draper et al. (2014).
Palm swamp forests make up the largest area of the studied peatlands (78\%). They are dominated by Mauritia flexuosa palms and are better known in Peru as aguajales. Pole forests, called varillales hidromórficos in Peru, make up $11 \%$ of the studied area; these dense forests consist of thin trees of limited diversity, with some species typical of white-sand forests (Draper et al. 2017). Grass-shrub swamps are also found to a lesser extent (11\%), and are dominated by herbaceous plants and shrubs. In addition to these, Lähteenoja et al. (2012) report the presence of peat in a forest seasonally flooded by black water (or tahuampa) in Loreto. In the Andes, peat is usually present in wetlands called bofedales (Maldonado 2014), in jalca ecosystems located at an altitude between 3,500 and 4,000 m (Cooper et al. 2010), in lacustrine sedge ecosystems known as totorales (Medrano et al. 2012) and in páramos (MINAM [Ministry of the Environment of Peru] 2018b). In the mountains, peatlands are characterized by the dominance of vascular cushion plants like Distichia spp., graminoids

Table 1. Estimated area of peatlands and ecosystems with the potential to form peat, by region

\begin{tabular}{lcl}
\hline Region & Estimated area of peatland $\left(\mathbf{k m}^{2}\right)$ & Ecosystem with the potential to form peat \\
\hline Amazon & $74,644^{\#}$ & Palm swamp forest \\
& & Pole forest \\
& Grass-shrub swamp \\
& Floodplain forest \\
\hline Andes & $13,800^{\&}$ & Bofedal \\
& & Páramo (moorland) \\
& & Jalca \\
\hline Coast & n.d. & Mangrove \\
& & Coastal wetland \\
\hline
\end{tabular}

Notes:

\# Gumbricht et al. (2017)

\& Estimated area only relevant in bofedales, according to Chimner (2019) based on Chimner et al. (2019).

$\$$ There are no studies enabling measurement of coastal peatland area. 
like Cortadeira spp. (Chimner et al. 2019), and sedges and mosses like Sphagnum spp. (Cooper et al. 2010; Benavides and Vitt 2014). In coastal areas, the presence of peat has been observed in mangroves (MINAM 2018b) and reedbeds (Ampuero and Aponte 2020).

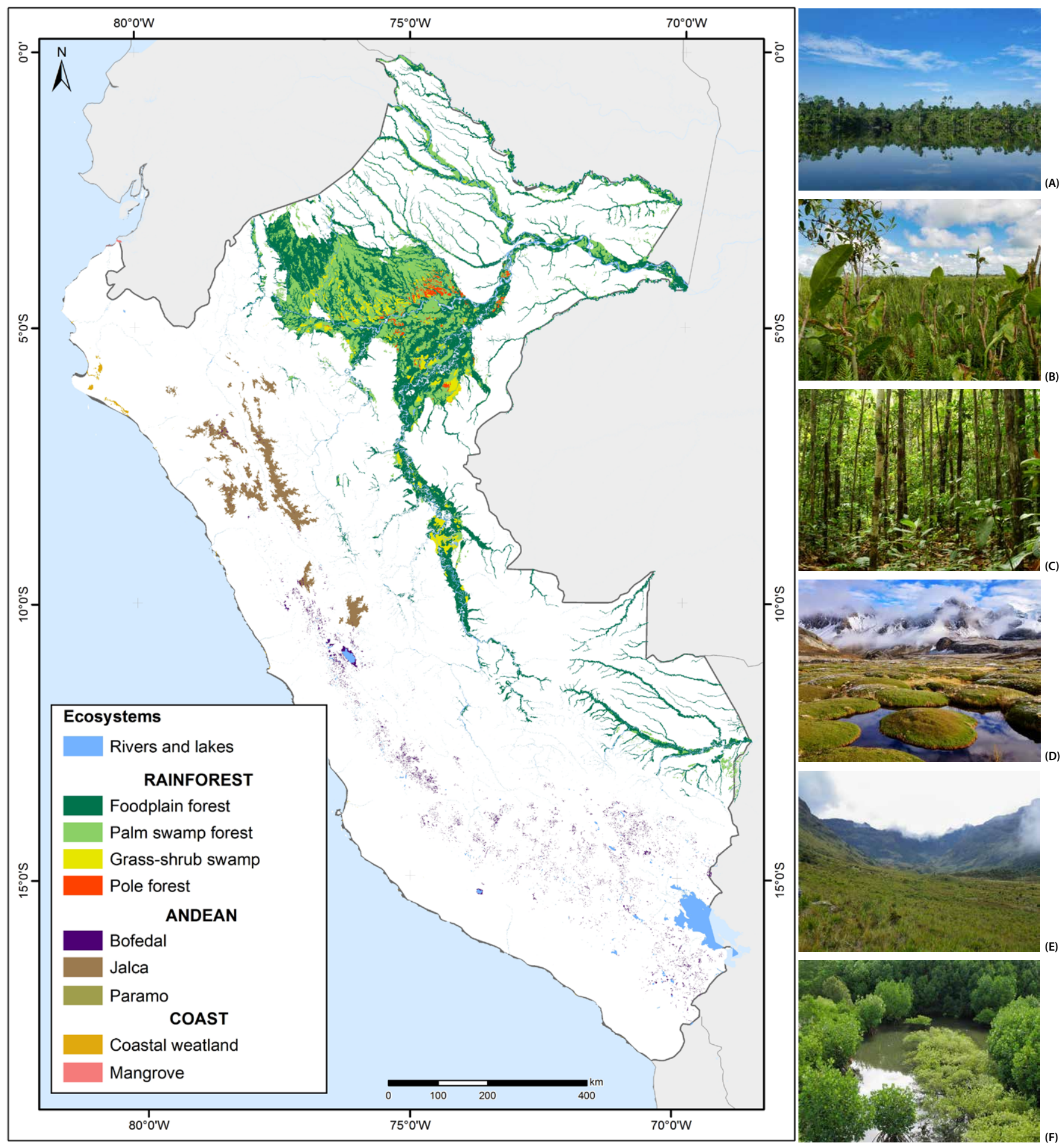

Figure 1. Ecosystems in Peru with the potential to form peat

Adapted from the MINAM ecosystem map (MINAM 2018b), with pole forest data from a study by Draper et al.

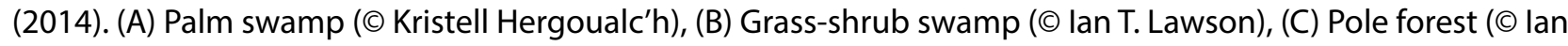

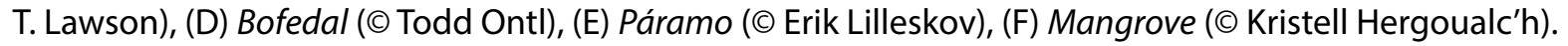


Research indicates that the formation of Peruvian peatlands began about 8,900 years ago in the Amazon (Swindles et al. 2017) and 9,300 years ago in the Andes (Planas et al. 2020). Reported averages for peat accumulation range from 1.9 to $2.2 \mathrm{~mm}$ year $^{-1}$ (Lähteenoja et al. 2009; Roucoux et al. 2013; Swindles et al. 2017), meaning that $10 \mathrm{~cm}$ of peat represents about 50 years of accumulation, without taking into account the influence of other factors like hydrology and climate. Carbon dating showed average accumulation rates of $66 \mathrm{~g} \mathrm{C} \mathrm{m}^{-2}$ year $^{-1}$ in the Amazon peatlands (Lähteenoja et al. 2009) and $59 \mathrm{~g} \mathrm{C} \mathrm{m}^{-2}$ year $^{-1}$ in the Andes (Huamán et al. 2017). These accumulation rates demonstrate the important role that Peruvian peatlands play in C sequestration.

The properties of the peat and its associated ecosystems are highly influenced by the topography and long-term climate. For example, in the north of the Pastaza-Marañón Foreland basin, the stability of the Tigre River has enabled the formation of pole forests underlaid by very deep peat which accumulates above the river flood level (Draper et al. 2014). Being ombrotrophic (i.e. dependent on precipitation for all water and nutrients), these pole forests have acidic soils poor in nutrients but high in $\mathrm{C}$ content. In contrast, minerotrophic peatlands (i.e. fed by rainfall and surface or underground river water) are richer in nutrients but have less $C$ content than ombrotrophic systems. It is estimated that, in Peru, $60 \%$ of Amazon peatlands are minerotrophic (Lähteenoja and Page 2011); Andean peatland data are insufficient to provide an estimation. The vast majority of peatlands studied in the puna and jalca highland marshes are minerotrophic (Cooper et al. 2010; Chimner et al. 2019); and although bofedal peatlands are commonly called ombrotrophic bogs, their hydrological characteristics suggest that they too are minerotrophic (Cooper et al. 2010; Chimner et al. 2019).

Peruvian peatlands are massive $\mathrm{C}$ reservoirs. It is estimated that in the Pastaza-Marañon Foreland basin alone, home to 3\% of the country's forest area (Saatchi et al. 2007), 3.1 Gt C is held in peatland soil and vegetation (Draper et al. 2014). These reserves alone represent about $50 \%$ of the $\mathrm{C}$ stored in aerial biomass across the whole of Peru (6.9 Gt C; Asner et al. 2014), and is equivalent to over 90 years of anthropogenic $\mathrm{CO}_{2}$ emissions of the country (0.13 Gt CO in 2014; MINAM 2019). In the Amazon, total $\mathrm{C}$ reserves (soil and vegetation) per unit area are on average $2-4$ times greater in peatlands than in terra firme forests (Baker et al. 2020). This difference is mainly due to the colossal reserves found in the soil. In the Pastaza basin, peat depths up to $7.5 \mathrm{~m}$ were recorded (Lähteenoja et al. 2012). In palm swamps, Bhomia et al. (2019) measured total $C$ stocks in the range of 200-1,600 t C ha- ${ }^{-1}$ with around 75\% (109-594 $\mathrm{t} \mathrm{C} \mathrm{ha}^{-1}$ ) concentrated in the first $100 \mathrm{~cm}$ of soil. Data on $\mathrm{C}$ depth and storage in Andean peatlands are more scarce, but peat depths of up to $10.5 \mathrm{~m}$ and soil stocks of 2,100 $\mathrm{t} \mathrm{C} \mathrm{ha}^{-1}$ were measured in bofedales (Hribljan et al. unpublished). Likewise, of the 36 jalca wetland plots sampled by Cooper et al. (2010) in Cajamarca, $17 \%$ had a peat depth greater than $7 \mathrm{~m}$, over $25 \%$ had a peat depth greater than $5 \mathrm{~m}$, and over $50 \%$ had a peat depth greater than $3 \mathrm{~m}$.

In addition to their capacity to store and sequester $\mathrm{C}$, peatlands play a fundamental role in regulating the hydrological cycle at landscape scale and provide a constant supply of water during the dry season (Maldonado Fonkén 2014). This hydrological regulation makes the regions where peatlands are found more resilient to adverse climate change effects like prolonged droughts and floods (García and Otto 2015).

Peatlands are also home to unique biodiversity. A wide variety of animals live in or pass through the palm swamps to obtain food and water (Gilmore et al. 2013). These animals include monkeys, macaws (especially the blue and yellow macaw - Ara ararauna, and the red-bellied macaw - Orthopsittaca manilatus), ungulates (especially tapir - Tapirus terrestris, and white-lipped peccary - Tayassu pecari), rodents like the common agouti - Dasyprocta spp. and lowland or spotted paca-Agouti paca, tortoises - Chelonoidis denticulata and fish. The fruit of the $M$. flexuosa palm in particular plays a very important role in the ecology and lifecycle of numerous species, especially the above mentioned ungulates (Bodmer et al. 1999). Some bird species are virtually only found in $M$. flexuosa swamps, like the point-tailed palmcreeper-Berlepschia rikeri, the moriche oriole - Icterus chrysocephalus, and the sulphury flycatcher - Tyrannopsis sulphurea. Similarly, pole forests are the habitat of birds that are both endangered and at risk of extinction, and they sustain species from other habitats. For their part, the Andean bofedales provide a home for a great variety of camelids and rodents, and serve as a feeding and nesting place for birds, including endangered species like white-bellied cinclodes Cinclodes palliatus (Maldonado Fonkén 2014). 
Both lowland and high Andean peatlands are fundamental to the livelihoods of local communities. Indigenous and riverside communities in the Amazon use peatland ecosystems for fishing, hunting and gathering plants. More than 50 species of plants are used for different purposes and form part of the local economy, including the fruit of $M$. flexuosa from palm swamps, whose consumption reaches 685 tons a month in the city of Iquitos alone (Horn et al. 2018). In bofedales, where climatic conditions render agriculture unviable, animal husbandry is the main source of income (Maldonado Fonkén 2014). Livestock mainly feed on herbaceous vegetation and the humidity of the peatland subsoil is essential for quality forage, and hereby meat and wool availability, especially in the driest parts of the Andes and during the driest months of the year. The bofedales are also very important for feeding wildlife, including the vicuna (Vicuana vicuana), whose wool is an important source of income for rural communities.

Finally, peatlands are an important part of the cultural roots of many indigenous communities, who integrate both physical and spiritual aspects in their cosmovision. They have detailed knowledge of their environment and are aware of the importance of sustainably managing wetlands (Martín et al. 2019; Schulz et al. 2019). Such is the case of the Urarina people in Loreto, and the Achuar people of the Pastaza who took their name from the palm $M$. flexuosa (called achu in Achuar), which is valued as sacred (Kahn et al. 1993). In the Andean cosmovision, wetlands are known by rural communities as oconales, a name derived from the Quechua word oqho, which refers to natural grasslands in humid environments (Salvador and Cano 2002). The communities value these ecosystems not only for their resources (which they primarily use to sustain livestock), but also for their cultural importance, which creates respect for the ecosystem and benefits its conservation. It is worth mentioning that many Andean wetlands, including peatlands, are artificial and were created by the local population over more than two thousand years through the construction and management of water channels which increased the expanse of wetlands (Verzijl and Guerrero 2013).

\subsection{Threats}

Causes of peatland degradation, both those which are common to all regions of Peru and those specific to each region, are summarized in Table 2. Any of these forms of degradation brings with it critical losses of $\mathrm{C}$ and GHG emissions, in much higher proportions than in ecosystems on mineral soil (Drösler et al. 2014; Oktarita et al. 2017).

In the Amazon, about $24 \%$ of the peatlands in the Pastaza basin are located in oil concessions (Roucoux et al. 2017). This, together with the development of road networks and other projected infrastructure, could alter the hydrological connectivity of the basin and cause a population migration that would accelerate peatland degradation through the expansion of the agricultural frontier, gold mining and overexploitation of resources (Lilleskov et al. 2017; Roucoux et al. 2017). One example is the planned highway to connect the Loreto region with the northern coast of Peru (Iquitos-Saramiriza Highway, Law 30670, Republic of Peru 2017). Although the highway's route is located beyond the limit of the Pastaza wetland complex - the largest Ramsar site in the Peruvian Amazon - it would pass near the deepest peat deposits in the entire basin (Baker et al. 2020). In addition, an electricity project to connect Iquitos with the National Interconnected Electric System (SIEN) announced five years ago, considered having one of its sections crossing the widest part of the Pastaza wetland complex, according to the Ministry of Energy and Mines.

Table 2. Main causes of peatland degradation in Peru

\begin{tabular}{ll}
\hline Region & Causes of degradation \\
\hline All & $\begin{array}{l}\text { Extractive, productive and high-impact service activities like the exploitation of oil and mining } \\
\text { resources, and road construction. Climate changes }\end{array}$ \\
Amazon & Selective felling of palm trees, land-use change, overhunting \\
Andes & Overgrazing, drainage, peat extraction \\
Coast & Anthropogenic fires \\
\hline
\end{tabular}


The peat ecosystems that have suffered the greatest degradation in recent decades are the palm swamps or aguajales. They have been unsustainably exploited for over 40 years (Padoch 1988) by the harvesting of $M$. flexuosa fruits through selectively felling female palms (Horn et al. 2012). A pilot study estimated that in an area of 350,000 hectares in the Ucayali and Marañón river basins, $73 \%$ of the aguajales had been degraded (Hergoualc'h et al. 2017). Over time, this practice reduces resources, modifies the forest structure and composition, stimulates peat decomposition and has the potential to stop peat formation (Hergoualc'h et al. 2017; van Lent et al. 2019). The impact of this practice on nitrous oxide and methane emissions from peat is concentrated at the micro-scale rather than at ecosystem level (Hergoualc'h et al. 2020). Although commercial agriculture has not yet expanded widely into the Amazon peatlands, there have been reports of plantations and rice fields being established in wetlands and palm swamps in regions like Madre de Dios (Janovec et al. 2013), Ucayali (Personal communication from Nuñez 2020) and San Martín (Noriega 2012). Finally, overhunting, as observed in the Peruvian Amazon's north (Aquino et al. 2007), decreases animal populations, which can reduce seed dispersal and alter the composition and structure of ecosystems, affecting functionalities like C storage (Peres et al. 2016; Bagchi et al. 2018).

In the Andes, mining activity and highways and dams construction alter the hydrology and/or pollute soils and water with sediment and toxic substances (Maldonado Fonkén 2014). This causes large-scale, immediate and long-term damage that affects surrounding populations and downstream waters. Bofedales have been used for grazing since pre-Hispanic times, but increasing overgrazing (especially by introduced hooved animals), burning, mismanagement and ditches construction are resulting in their progressive loss (RománCuesta et al. 2011; Salvador et al. 2014; Garcia and Otto 2015; ANA 2018; Planas et al. 2020). Overgrazing causes four main types of impact: (a) it reduces organic matter inputs to the soil, which reduces peat formation; (b) it modifies soil physical properties (e.g. through compaction); (c) it increases methane emissions (Sánchez et al. 2017); and (d) it favors peat decomposition, in cases of drainage, to facilitate livestock access (Planas et al. 2020). The absence of peatlands demarcation and zoning in bofedales hampers efforts to improve their management and redirect grazing towards areas without peat (Chimner et al. 2019). On the other hand, the extraction of peat for its use in agro-export crops and horticulture, carried out by people outside the communities, has increased alarmingly in recent years (Machuca 2018; Ziegler 2020), affecting the livestock production system and contributing to the rapid depletion and irreparable loss of the resource.

On the coast, anthropogenic fires in wetlands occur frequently (Aponte et al. 2015), the consequences of which are yet to be evaluated, in terms of their impact on biological diversity. These fires release high quantities of GHG into the atmosphere, and substantially reduce $\mathrm{C}$ stocks (Ampuero and Aponte 2020).

Peatlands are also threatened by global climate changes and can be significantly impacted by the intensification of climatic events like droughts and floods, and rising temperatures (Roucoux et al. 2017; Swindles et al. 2017). According to Swindles et al. (2017), future droughts in the Amazon will have different consequences, depending on the specific ecosystem. Droughts could lead to rapid $\mathrm{C}$ accumulation phases in some peat swamps (by increasing their net primary productivity), which could ultimately lead to the system's ombrotrophication (i.e. succession from a minerotrophic to an ombrotrophic state), and a subsequent return to a slower $\mathrm{C}$ accumulation. Conversely, in ombrotrophic systems, droughts could reduce $\mathrm{C}$ accumulation or even induce a net peat loss. Long drought periods along with a water table drawdown could also favor fires (Lilleskov et al. 2017). A wetter climate (Swindles et al. 2017) and intense floods as observed in the eastern Amazon in recent decades (Gloor et al. 2013), would potentially have the opposite impacts on $\mathrm{C}$ sequestration to those in times of drought. An increase in precipitation would likewise increase methane emissions in palm swamps (Hergoualc'h et al. 2020). In the Andes, although peatlands' vulnerability to climate change is closely linked to less water availability (ANA 2018), the retreat of glaciers conceals processes that go beyond the impact on their water reserves. Among them is the extreme erosion that is suffered by areas that have melted and that contain toxic substances like acid rock drainage, which pollutes the bofedales, and affects local populations and their livestock (Angulo et al. 2017; INAIGEM 2017). On the other hand, a temperature increase of $0.5^{\circ} \mathrm{C}$ by 2100 (RCP Scenario 2.6 of the Intergovernmental Panel on Climate Change; IPCC 2014) in the 
Pastaza-Marañón foreland basin would decrease the accumulation rate of organic $\mathrm{C}$ in peat (Wang et al. 2018). An increase of $2.7^{\circ} \mathrm{C}$ (RCP Scenario 8.5) would accelerate peat $\mathrm{C}$ loss, which would turn the region's peatlands into a source of $\mathrm{C}$ to the atmosphere, at a rate of $53 \mathrm{~g} \mathrm{C} \mathrm{m}^{-2}$ year ${ }^{1}$.

\subsection{Regulatory framework}

Peru has regulations and instruments related to sustainable management of wetlands, and by defect of peatlands. However, this regulatory framework that covers wetlands, and refers to palm swamps, bofedales and peatlands, does not include a specific definition or regulations for peatlands, which puts their integrity at risk. These are critical to ensure peatlands' sustainable management, considering their importance and vulnerability according to existing scientific evidence, and their contribution to meeting Peru's international commitments, in the framework of the Paris Agreement and other international agreements. The National Wetlands Strategy (MINAM 2015), for example, whose objective is to promote wetlands conservation and sustainable use, needs to consider the great variety of peatlands in the country, how their extent differ from that of other wetlands, and their key role in C stocks and sequestration. Similarly, given that the vast majority of the country's peatlands are forests, the National Strategy on Forests and Climate Change (MINAM 2016) should refer to the National Wetlands Strategy. It is also extremely important that, in its analysis of the underlying causes of deforestation, the National Strategy on Forests and Climate Change removes the recommendation to "provide advice in order to implement or improve some technologies, such as those used to drain wetlands", in order to "reduce the migration of indigenous and rural populations to fertile soils and/or non-deforested areas" (page 60). While the country is committed to tackling climate change and has formulated adaptation and mitigation goals in its Nationally Determined Contributions (NDC) as part of the Paris Agreement, it has not yet taken into account the potential of peatlands in its measures to mitigate GHG emissions or adapt to climate change (Republic of Peru 2015). The updated NDC considers wetlands and bofedales among four measures related to adaptation to climate change, but the explicit inclusion of peatlands is pending, especially in mitigation measures (GTM-NDC 2018). Likewise, peatlands and their immense $C$ reserves have yet to be incorporated into Peru's Reduction of Emissions from Deforestation and Forest Degradation (REDD+) strategy.

Some peatland areas (e.g. Pacaya Samiria Reserve, Tamshiyacu Tahuayo, Sierra del Divisor) are protected through their inclusion in conservation and ecological protection forest zones or protected natural areas (Law No. 26834, Republic of Peru 1997). Similarly, there are national parks, like the recently created Yaguas National Park (Supreme Decree No. 001-2018-MINAM, MINAM 2018a), that contain extensive areas of peat swamps (Baker et al. 2020). The vast majority of the PastazaMarañón foreland basin peatlands, despite being part of a Ramsar site and included to a certain extent in lands titled to indigenous communities, are in need of complementary measures to ensure their protection and effective management. For example, the Tigre River pole forests - the peat ecosystems with the highest $\mathrm{C}$ density so far measured in the Amazon basin - have just a Ramsar site designation (Roucoux et al. 2017). In the same way, extensive areas of bofedales lack any kind of protection, even though they are invaluable water catchment, storage and regulation areas, vital for both the surrounding population and those leaving downstream.

That said, Peru does have important regulations on mechanisms for the compensation of ecosystem services. At national level, the National Superintendence for Sanitation Services (SUNASS in Spanish) is supporting the conservation and/ or restoration of ecosystems located upstream of river basins - including ecosystems with peat forming potential - by allocating funds to the water tariff of various Sanitation Service Providers (EPS in Spanish) (Law 30215, Supreme Decree $\mathrm{N}^{\circ}$ 009-2016-MINAM, Republic of Peru 2016). Also under the 'payment for ecosystem services' scheme, the MERESE-FIDE project (proyecto MERESE-FIDA) is channeling resources towards the conservation, restoration and sustainable use of Andean ecosystems, including bofedales, through Global Environment Fund (GEF) financing under the administration of MINAM (Law 30215).

Finally, Peru has interinstitutional coordination bodies working on wetlands, like the National Wetlands Committee (NWC), whose objective is to promote the appropriate management of wetlands, and to monitor the implementation of national commitments under the Ramsar Convention. 


\section{Opportunities and challenges}

The conservation and sustainable use of peatlands in Peru depend upon the: (1) strengthening of the regulatory framework; (2) reinforcement of financial mechanisms and promotion of both public and private investment (in collaboration with local communities); (3) improvement of scientific research; and (4) acknowledgement of the value and importance of indigenous knowledge.

Lilleskov et al. (2017) made a list of policy options in which peatlands need to be explicitly included. Based on this list, we suggest to evaluate, promote or develop those options related to: a) ban drainage of peatlands for any kind of activity, and development of road networks or exploration routes, and infrastructure for the extraction of resources (minerals, gas, oil) in these areas; b) development of agricultural and forestry plans that includes the unique susceptibilities of peatlands (e.g. fire risk); and c) effective implementation of regulations for those activities that impact peatlands, like illegal felling, or peat extraction and commercialization.

To promote effective peatland conservation, it is vital to strengthen multisectoral and interinstitutional coordination across the different stakeholders and levels of government. It is necessary to clarify the functions of the different institutions involved in their conservation and management: MINAM, MINAGRI - Ministry of Agriculture and Irrigation (and their affiliates SERFOR - National Forestry and Wildlife Service, and ANA - National Water Authority), PRODUCE - Ministry of Production, subnational governments and other key stakeholders. The National Wetlands Committee (NWC) is the appropriate body for coordination, and a suitable place to encourage discussions so as to improve the overall management of peatlands. The NWC has recently begun to promote sustainable peatland management. Initial measures towards this goal include the development of a technical guide to set a national definition for peatlands, which identifies ecosystems with a proven presence or potential to form peat. The adoption of a national definition, agreed upon by the different stakeholders, will be essential to improve existing policies that protect peatlands or develop new ones, and include them in strategies for climate change mitigation and adaptation, biodiversity conservation, sustainable wetland and water resource management, and strategies to combat desertification and drought. The definition will also be of great use to highlight the importance of peatlands as water regulators in green infrastructures, as per the Sustainable Development Goals (SDG) assumed by the country, specifically the water and sanitation goal (SDG 6). Elsewhere, the ANA, in coordination with the NWC, is generating hydrological information for the development of a national wetlands inventory - a technical tool that aims at supporting wetlands management and conservation at different levels of government (national, regional and local). This inventory will lay the foundation for the identification and classification of Peru's peatlands. MINAM is also pushing for a national regulation to promote the conservation and comprehensive management of the country's wetlands, including peatlands.

It is important for peatlands to be explicitly considered when the NDCs and REDD+ mechanism are updated. Although Peru currently lacks activity data and precise emission factors, there is enough information to set targets around the reduction of emissions from peatlands. For example, if a sustainable management plan for palm swamp peatlands was effectively implemented - preventing the destructive felling of palms through fruit-harvesting climbers, and rehabilitating a highly degraded area of $277 \mathrm{~km}^{2}$ (just $1 \%$ of this ecosystem's surface area in PastazaMarañón, according to Draper et al. 2014) - this would result in soil $\mathrm{CO}_{2}$ emissions reductions 
of $0.54 \mathrm{Mt}_{\text {year }}{ }^{-1}\left(1 \mathrm{Mt}=10^{12} \mathrm{~g}\right)$. Over 10 years, this represents up to $6 \%$ of Peru's current reduction goals by $2030\left(89 \mathrm{Mt} \mathrm{CO}_{2 \mathrm{eq}}\right)$. These projected estimations are based on the IPCC $\mathrm{CO}_{2}$ emission factor for peat decomposition in drained forests $\left(5.3 \mathrm{t} \mathrm{C} \mathrm{ha}^{-1}\right.$ year $^{-1}$, Table 2.1 in Drösler et al. 2014), and underestimate the mitigation potential, as they exclude $\mathrm{C}$ sequestration through vegetation regeneration.

Another significant opportunity for Peruvian peatland conservation is through the national Protected Natural Areas (PNA) system. Although precise area is unknown, approximately a third of all PNAs in Peru have bofedales (Maldonado 2010). In the Amazon, $23 \%$ of the Pastaza Maranón peatland complex is located in large national and regional reserves, like the Pacaya Samiria National Reserve (Roucoux et al. 2017). It has been demonstrated that sustainable management of wild flora and fauna and hydrobiological resources can be promoted in PNAs, through communities extracting certain renewable natural resources. This is the case in Pacaya Samiria National Reserve, where the sustainable harvest of aguaje palm fruit through climbing generates significant income for local people, and prevents forest degradation by adding value to the resources (Falen and Honorio 2018; SERNANP 2020). If peatland areas were to be included in the PNA system, their vulnerability to degradation at the hands of humans must be considered, along with their ecosystem services like $\mathrm{C}$ uptake and storage, and water conservation and flood control. Conservation through sustainably managing peatlands outside of the PNAs can also be done by prioritizing them as ecological conservation and protection areas, within the country's forest zoning process and the ecological and economic zoning processes that are being put forward by sub-national governments. Land tenure by rural and indigenous communities is recognized as another key factor in managing and conserving ecosystems, as well as helping to reduce poverty and food insecurity (MINAM 2015). Local communities currently own just $7 \%$ of the total peatland area in the PastazaMarañón Foreland basin (Roucoux et al. 2017), an insufficient share to enable its conservation. This fact should be taken into account when planning processes are developed for new infrastructure and other activities with potential impacts. Evidence connecting the loss of traditional knowledge with ecosystem degradation is increasingly abundant (Harmon 1996; Ross 2002; Loh and Harmon 2014; Pröpper and Haupts 2014; Schulz et al. 2019). It is therefore critically important to preserve the traditional knowledge, values and practices of indigenous peoples; likewise, strengthening the adaptive capacities of these communities to respond to new pressures and changes will undoubtedly contribute to peatland conservation in Peru (Martín et al. 2019). Whichever conservation and sustainable management option (or options) is chosen, the strategy's equity and cost-effectiveness must be considered, along with any risks associated with conflicts and poor governance.

Conserving, sustainably managing, restoring and enhancing the value of Peru's peatlands requires public and private, national and international investment. Looking at ongoing initiatives, the Datem of Marañón Wetlands Project (proyecto Humedales del Datem del Marañón) implemented by the National Fund for Protected Natural Areas (PROFONANPE) with funding from the Green Climate Fund - promotes initiatives that protect the $\mathrm{C}$ stocks of aguajales and the resilience of indigenous populations through bio-businesses. There is also the Natural Infrastructure Project (proyecto de Infraestructura Natural) financed by USAID, which contributes to the conservation, restoration and recuperation of ecosystems, notably of bofedales, as part of the country's efforts for water security. Private sector investments include the $\mathrm{BIO}$ beverage project by AJE, in association with the NGO Naturaleza y Cultura Internacional; it provides technical assistance to local communities in terms of organization, training, and equipment, so they can harvest $M$. flexuosa fruits without cutting down palms or degrading the forest (Tropical Forest Alliance 2020).

Both strengthening the regulatory framework and conserving and managing peat ecosystems must be based on sound science. Although there are guides, tools and global studies like the Global Wetlands Map (Gumbricht et al. 2017) and the IPCC 2013 Wetlands Supplement for National GHG Inventories (Hiraishi et al. 2014) that enable preliminary inventories, the country has yet to produce its own data. A relevant first step is for Peru to generate a national map and inventory of its peatlands, to clarify their exact location and quantify both their size and their $\mathrm{C}$ stocks, which are currently being estimated by specific 
studies. Research gaps on Peruvian peatlands remain important despite significant progress in recent years (Draper et al. 2014; Hergoualc'h et al. 2017; Falen and Honorio 2018; Bhomia et al. 2019; Chimner et al. 2019; Freitas et al. 2019;
Schulz et al. 2019; van Lent et al. 2019; Griffis et al. 2020). Table 3 presents the areas of research that are needed to improve knowledge essential for the protection and sustainable management of Peru's peatlands.

Table 3. Scientific research required for the protection and sustainable management of Peruvian peatlands

\begin{tabular}{|c|c|}
\hline Objectives & Research required \\
\hline \multirow{4}{*}{$\begin{array}{l}\text { Knowledge of peatland } \\
\text { distribution, functioning } \\
\text { and ecosystem services }\end{array}$} & National classification and mapping of peat ecosystems and their $\mathrm{C}$ reserves \\
\hline & $\begin{array}{l}\text { Detailed measurement of } C \text { storage in peat ecosystems with emphasis on soil } C \text {; } \\
\text { inventories of their biodiversity }\end{array}$ \\
\hline & Long-term monitoring of water, organic matter and GHG flux balances \\
\hline & $\begin{array}{l}\text { Hydrogeological studies in peatlands and modeling of water requirements: in } \\
\text { particular, ecological flow in areas with water deficits and watershed headwaters }\end{array}$ \\
\hline \multirow{5}{*}{$\begin{array}{l}\text { Knowledge of peatland } \\
\text { degradation drivers, } \\
\text { impacts, extent and } \\
\text { location }\end{array}$} & $\begin{array}{l}\text { Identification of degradation drivers (e.g. infrastructure, mining, overgrazing in the } \\
\text { Andes, felling of } M \text {. flexuosa in the Amazon, land-use change, pollution) and of their } \\
\text { geographic locations }\end{array}$ \\
\hline & Mapping of users, that identifies the legal or customary basis for their rights and uses \\
\hline & Mapping and monitoring of peatland degradation by intensity level \\
\hline & $\begin{array}{l}\text { Evaluation of degradation impacts on C stocks and sequestration, GHG fluxes, water } \\
\text { flow and resources (e.g. forage in the Andes, } M \text {. flexuosa fruit in the Amazon) }\end{array}$ \\
\hline & $\begin{array}{l}\text { Evaluation of climate change impact on the functioning of peatlands, including their } \\
\text { capacity to sequester } C \text {, regulate water and provide resources (e.g. modifications in } \\
\text { reproductive phenology behavior and } M \text {. flexuosa fruit production in the Amazon) }\end{array}$ \\
\hline \multirow{3}{*}{$\begin{array}{l}\text { Knowledge to reduce } \\
\text { anthropogenic pressures } \\
\text { on peatland ecosystems }\end{array}$} & $\begin{array}{l}\text { Investigating and valuing the knowledge and traditional practices of rural and } \\
\text { indigenous communities }\end{array}$ \\
\hline & $\begin{array}{l}\text { Studies on natural forests sustainable management, and silviculture and } \\
\text { plantation techniques (e.g. genetic improvement of the M. flexuosa species for its } \\
\text { establishment in plantations) }\end{array}$ \\
\hline & $\begin{array}{l}\text { Studies on comprehensive use of ecosystems' resources (e.g. nutritional value of } M \text {. } \\
\text { flexuosa floral parts and pollen) }\end{array}$ \\
\hline \multirow{3}{*}{$\begin{array}{l}\text { Knowledge for the } \\
\text { restoration of degraded } \\
\text { peatlands }\end{array}$} & Evaluation of the location and extent of restoration needs \\
\hline & $\begin{array}{l}\text { Studies of peatland restoration techniques like rewetting drained systems or } \\
\text { plantation of } M \text {. flexuosa in degraded palm swamps }\end{array}$ \\
\hline & $\begin{array}{l}\text { Evaluation of the effectiveness of restoration treatments in terms of hydrology, C } \\
\text { sequestration, GHG emissions }\end{array}$ \\
\hline
\end{tabular}




\section{Recommendations}

To maintain their integrity, Peruvian peatlands must be identified, mapped and explicitly recognized by government policies. As a first step, a national definition of peatlands has to be adopted; this will enable their inclusion in existing regulations or in the development of new ones.

The NWC, which coordinates aspects related to the Ramsar Convention in a multisectoral and interinstitutional manner, is the ideal arena to strengthen the existing legal framework so it prioritizes peatlands. For coordinated efforts it is vital that the NWC collaborates closely with regional and local governments, relevant public organizations, and other key stakeholders like indigenous and rural organizations.

Peatland conservation, sustainable management and restoration programs, whether public or private, must consider the development objectives of surrounding communities so as to optimize ecological, economic and social co-benefits. Local communities directly benefitting from peatlands goods and services are the best guarantee that peatlands will conserve the entirety of their functions. Likewise, it is relevant to develop market strategies that invest in transformative technology to add value to products from managed peatlands, and to get those technologies transferred to the local population. In this regard, given the limited capacities of local communities, the participation of private national and international companies is extremely important.

The tenure rights of communities inhabiting peatlands must be strengthened so that they invest in good management practices. It is also essential to validate the sustainability of traditional practices, in collaboration with local institutions that facilitate conservation in these areas.

Policies and interventions in peatlands must be based on scientific evidence. It is critical to invest in deepening and promoting scientific knowledge and to facilitate its transfer through agreements among universities, non-governmental organizations, sectors involved in peatlands conservation and international platforms (e.g. GPI, ITPC). There is also a need to develop technical training and public-facing education and outreach programs on peatlands. Finally, it is vital that the ancestral knowledge of indigenous communities is considered; this will enable the identification and valuation of ancient customs and techniques practiced by these communities in managing their wetlands. 


\section{References}

Ampuero W and Aponte H. 2020. Estimación del carbono almacenado en un juncal de Schoenoplectus americanus en el humedal costero Los Pantanos de Villa (Lima-Perú). Arnaldoa 27(1):e157-64.

[ANA] Autoridad Nacional del Agua. 2018. Estudio piloto. Inventario de humedales en el ámbito de la ALA Pisco. ANA.

Angulo Ó and De Biévre B. 2017. Impacts of glaciers retreat on highland Andean wetlands and communities: Lessons from the upper Cachi catchment (Ayacucho, Peru). Geophysical Research Abstracts 19, EGU2017.

Aponte H, Ramírez D, Lértora G, Vargas R, Gil F, Carazas N and Livial R. 2015. Incendios en los humedales de la costa central del Perú: Una amenaza frecuente. Cientifica 12(1):70-81.

Aquino R, Terrones C, Navarro R and Terrones W. 2007. Evaluación del impacto de la caza en mamíferos de la cuenca del río Alto Itaya, Amazonía peruana. Revista Peruana de Biología 14(2):181-6.

Asner G, Knapp D, Martin R, Tupayachi R, Anderson C, Mascaro J, Sinca F, Chadwick D, Sousan S, Higgins M, et al. 2014. The high-resolution carbon geography of Peru. Lima: Carnegie Airborne Observatory and the Ministry of Environment of Peru.

Avitabile V, Herold M, Heuvelink G, Lewis S, et al. 2015. An integrated pan-tropical biomass map using multiple reference datasets. Global Change Biology 22(4):1406-20.

Bagchi R, Swamy V, Latorre Farfán JP, Terborgh J, Vela C, Pitman N and Galiano W. 2018. Defaunation increases the spatial clustering of lowland Western Amazonian tree communities. Journal of Ecology 106:1470-82.

Baker T, Del Castillo D, Honorio E, Lawson I, Martín M, Montoya M and Roucoux K. 2020. The challenges for achieving conservation and sustainable development within the wetlands of the Pastaza-Marañon basin, Peru. In Chirif Tirado A, ed., Peru: Deforestation in Times of Climate Change. Lima: IWGIA. 155-74.

Benavides J and Vitt D. 2014. Response curves and the environmental limits for peat-forming species in the northern Andes. Plant Ecology 215:937-52.

Bhomia R, Van Lent J, Grandez J, Hergoualc'h K, Honorio E and Murdiyarso D. 2019. Impacts of Mauritia flexuosa degradation on the carbon stocks of freshwater peatlands in the PastazaMarañón river basin of the Peruvian Amazon. Mitigation and Adaptation Strategies for Global Change 24:645-68.

Bodmer R, Puertas P, García J, Días D and Reyes C. 1999. Game animals, palms, and people of the flooded forests: Management considerations for the Pacaya-Samiria National Reserve, Peru. Advances in Economic Botany 13:217-31.

Chimner R. 2019. Reservas de carbono y ciclos de carbono de las turberas andinas. National symposium on sustainable management of Peruvian peatlands. Lima: CIFOR. https:// www.slideshare.net/CIFOR/reservasde-carbono-y-ciclo-de-carbono-de-lasturberas-andinas

Chimner R, Bourgeau-Chávez L, Grelik S, Hribljan J, Planas A, Polk M, Lilleskov E and Fuentealba B. 2019. Mapping mountain peatlands and wet meadows using multi-date, multi-sensor remote sensing in the Cordillera Blanca, Peru. Wetlands 39:1057-67. https:// doi.org/10.1007/s13157-019-01134-1

Cooper DJ, Wolf EC, Colson C, Vering W, Granda A and Meyer M. 2010. Alpine peatlands of the Andes, Cajamarca, Peru. Arctic Antarctic and Alpine Research 42:19-33.

Draper F, Coronado E, Roucoux K, Lawson I, Pitman N, Fine P, Phillips O, Montenegro L, Sandoval E, Mesones I, et al. 2017. Peatland forests are the least diverse tree communities documented in Amazonia, but contribute 
to high regional beta-diversity. Ecography 41:1256-69.

Draper F, Roucoux K, Lawson I, Mitchard E, Honorio E, Lähteenoja O, Torres L, Valderrama E, Zaráte R and Baker T. 2014. The distribution and amount of carbon in the largest peatland complex in Amazonia. Environmental Research Letters 9:124017-29.

Drösler M, Verchot L, Freibauer A, Pan G, Evans C, Bourbonniere R, Alm J, Page S, Agus F, Hergoualc'h K, et al. 2014. Drained inland organic soils. In Hiraishi T, Krug T, Tanabe K, Srivastava N, Jamsranjav B, Fukuda M y Troxler T, eds., 2013 Supplement to the 2006 IPCC Guidelines for National Greenhouse Gas Inventories: Wetlands. Geneva: IPCC.

Falen L and Honorio E. 2018. Evaluación de las técnicas de aprovechamiento de frutos de aguaje (Mauritia flexuosa L.f.) en el distrito de Jenaro Herrera, Loreto, Perú. Folia Amazónica 27:131-50.

Freitas L, Zárate R, Bardales R and Del Castillo D. 2019. Efecto de la densidad de siembra en el desarrollo vegetativo del aguaje (Mauritia flexuosa L.f.) en plantaciones forestales. Revista Peruana de Biología 26(2):227-34.

García E and Otto M. 2015. Caracterización ecohidrológica de humedales altoandinos usando imágenes de satélite multitemporales en la cabecera de cuenca del río Santa, Áncash, Perú. Ecología Aplicada 14(2):115-125.

Gaveau D, Salim M, Hergoaualc'h K, Locatelli B, Sloan S, Wooster M, Marlier M, Molidena E, Yaen H, DeFries R, et al. 2014. Major atmospheric emissions from peat fires in Southeast Asia during non-drought years: Evidence from the 2013 Sumatran fires. Scientific Reports 4, 6112.

Gilmore MP, Endress BA and Horn CM. 2013. The socio-cultural importance of Mauritia flexuosa palm swamps (aguajales) and implications for multi-use management in two Maijuna communities of the Peruvian Amazon. Journal of Ethnobiology and Ethnomedicine 9(29). https://doi.org/10.1186/1746-4269-9-29

Gloor M, Brienen R, Galbraith D, Feldpausch T, Schongart J, Guyot J, Espinoza J, Lloyd J and Phillips O. 2013. Intensification of the Amazon hydrological cycle over the last two decades. Geophysical Research Letters 40:1729-33.

Griffis T, Roman T, Wood J, Deventer J, Fachin L, Rengifo J, Del Castillo D, Lilleskov E, Kolka R, Chimner R, et al. 2020. Hydrometeorological sensitivities of net ecosystem carbon dioxide and methane exchange of an Amazonian palm swamp peatland. Agricultural and Forest Meteorology 295.

Griscom B, Adams J, Ellis P, Houghton R, Lomax G, Miteva D, Schlesinger WH, Shoch D, Siikamäki JV, Smith P, et al. 2017. Natural climate solutions. Proceedings of the National Academy of Sciences of the United States of America 114:11645-50.

[GTM-NDC] Grupo de Trabajo Multisectorial para la Implementación de las NDC. 2018. Informe final. http://www.minam.gob.pe/ cambioclimatico/gtm/

Gumbricht T, Román-Cuesta R, Verchot L, Herold M, Wittmann F, Householder E, Herold N and Murdiyarso D. 2017. An expert system model for mapping tropical wetlands and peatlands reveals South America as the largest contributor. Global Change Biology 23:3581-99.

Harmon D. 1996. Losing species, losing languages: Connections between biological and linguistic diversity. Southwest Journal of Linguistics (15):89-108.

Hergoualc'h K, Carmenta R, Atmadja S, Martius C, Murdiyarso D and Purnomo H. 2018. Managing peatlands in Indonesia: Challenges and opportunities for local and global communities. CIFOR Infobrief 205. Bogor, Indonesia: CIFOR.

Hergoualc'h K, Dezzeo N, Verchot C, Van Lent J, Del Águila J and López M. 2020. Spatial and temporal variability of soil $\mathrm{N}_{2} \mathrm{O}$ and $\mathrm{CH}_{4}$ fluxes along a degradation gradient in a palm swamp peat forest in the Peruvian Amazon. Global Change Biology. doi:10.1111/gcb.15354

Hergoualc'h K, Gutiérrez-Vélez V, Menton M and Verchot L. 2017. Characterizing degradation of palm swamp peatlands from space and on the ground: An exploratory study in the Peruvian Amazon. Forest Ecology and Management 393:63-73.

Hiraishi T, Krug T, Tanabe K, Srivastava N, Fukuda M, Troxler T and Jamsranjav B. 2013. Supplement to the 2006 IPCC Guidelines for National Greenhouse Gas Inventories: Wetlands. Geneva: IPCC. Accessed 13 February 2018. http://www.ipcc-nggip.iges.or.jp/public/ wetlands/pdf/Wetlands_Supplement_Entire_ Report.pdf

Horn C, Gilmore M and Endress B. 2012. Ecological and socio-economic factors influencing aguaje (Mauritia flexuosa) resource management in two indigenous communities in the Peruvian Amazon forest. Forest Ecology and Management 267:93-103. 
Horn C, Paredes V, Gilmore M and Endress B. 2018. Spatio-temporal patterns of Mauritia flexuosa fruit extraction in the Peruvian Amazon: Implications for conservation and sustainability. Applied Geography 97:98-108.

Hribljan J, Suárez E, Bourgeau-Chávez L, Endres S, Lilleskov E, Chimbolema S, Wayson C, Serocki E and Chimner R. 2017. Multidate, multisensor remote sensing reveals high density of carbon rich mountain peatlands in the páramo of Ecuador. Global Change Biology 23(12):541225. https://doi.org/10.1111/gcb.13807

Huamán Y, Moreira-Turq P, Willems B, Espinoza R, Apaéstegui J and Llanos R. 2017. Cambios en la acumulación de carbono en bofedales andinos durantes los últimos 3000 años. Peruvian Congress of Wetlands.

[INAIGEM] Instituto Nacional de Investigación en Glaciares y Ecosistemas de Montaña. 2017. Informe de la situación de los glaciares y ecosistemas de montaña.

[IPCC] Intergovernmental Panel on Climate Change. 2014. Climate Change 2014: Synthesis Report. Contribution of Working Groups I, II and III to the Fifth Assessment Report of the Intergovernmental Panel on Climate Change. Geneva: IPCC. https://ar5-syr.ipcc.ch/topic_ summary.php

Janovec J, Householder E, Tobler M, Valega R, Von May R, Araujo J, Zelski S, Shearer C, Jiménez M, Wells J, et al. 2013. Humedales de Madre de Dios, Perú: impactos y amenazas en aguajales y cochas. Lima: WWF.

Kahn F, Mejía K, Moussa F and Gómez D. 1993. Mauritia flexuosa, la más acuática de las palmeras amazónicas. In Kahn F, León B and Young $\mathrm{K}$, Las plantas vasculares en las aguas continentales del Perú 75:8(287-308).

Lähteenoja O and Page S. 2011. High diversity of tropical peatland ecosystem types in the PastazaMaranon basin, Peruvian Amazonia. Journal of Geophysical Research-Biogeosciences 116.

Lähteenoja O, Reátegui Y, Rasanen M, Del Castillo D, Oinonen M and Page S. 2012. The large Amazonian peatland carbon sink in the subsiding Pastaza-Marañon foreland basin, Peru. Global Change Biology 18:164-78.

Lähteenoja O, Ruokolainen K, Schulman L and Oinonen M. 2009. Amazonian peatlands: An ignored C sink and potential source. Global Change Biology 15:2311-20.

Lilleskov E, McCullough K, Hergoualc'h K, Del Castillo D, Chimner R, Murdiyarso D, Kolka R, Bourgeau R, Hribljan J, Del Águila J and
Wayson C. 2017. Is Indonesian peatland loss a cautionary tale for Peru? A two-country comparison of the magnitude and causes of tropical peatland degradation. Mitigation and Adaptation Strategies for Global Change 24:591-623.

Loh J and Harmon D. 2014. Biocultural diversity: Threatened species, endangered languages. Netherlands: WWF-Netherlands.

Machuca D. 2018. Efectos de la extracción de turba en un sistema socioecológico andino: Bofedales de Carampoma - Lima [BA thesis]. Lima: Pontificia Universidad Católica del Perú.

Maldonado M. 2010. Comportamiento de la vegetación de bofedales influenciados por actividades antrópicas [Master's thesis]. Lima: Pontificia Universidad Católica del Perú.

Maldonado Fonkén M. 2014. An introduction to the bofedales of the Peruvian high Andes. Mires Peat 15:1-13.

Martín M, Núñez C, Fabiano E, Del Águila M, Shulz C, Laurie N, Sanjurjo J, Davies A, Roucoux K, Lawson I and Andueza L. 2019. Urarina: Identidad y memoria en la cuenca del rio Chambira. Iquitos: IIAP/MINAM; PUCP; University of Saint Andrews.

Medrano R, Chupan L and Vila M. 2012. Almacenamiento de carbono en especies predominantes de flora en el lago Chinchaycocha. Apuntes de Ciencia y Sociedad 2(2):110-117.

Melack JM, Hess LL, Gastil M, Forsberg BR, Hamilton SK, Lima IB and Novo EM. 2004. Regionalization of methane emissions in the Amazon Basin with microwave remote sensing. Global Change Biology 10:530-44.

Miettinen J, Hooijer A, Shi C, Tollenaar D, Vernimmen R, Liew S, Malins $C$ and Page S. 2012. Extent of industrial plantations on Southeast Asian peatlands in 2010 with analysis of historical expansion and future projections. GCB Bioenergy 4(6):908-18. https://doi.org/10.1111/j.17571707.2012.01172.x

[MINAM] Ministerio del Ambiente del Perú. 2019. Inventario Nacional de Gases de Efecto Invernadero (INGEI) 2014.

[MINAM] Ministerio del Ambiente del Perú. 2018a. Decreto Supremo que aprueba la categorización de la Zona Reservada Yaguas como Parque Nacional Yaguas. Supreme Decree No. 001-2018-MINAM. Lima: MINAM.

[MINAM] Ministerio del Ambiente del Perú. 2018b. Mapa de ecosistemas del Perú. 
Memoria descriptiva. Lima: MINAM. https:// sinia.minam.gob.pe/mapas/mapa-nacionalecosistemas-peru

[MINAM] Ministerio del Ambiente del Perú. 2016. Estrategia Nacional sobre Bosques y Cambio Climático. Supreme Decree no. 007-2016-MINAM. http:// www.bosques.gob.pe/archivo/ff3f54_ ESTRATEGIACAMBIOCLIMATICO2016_ ok.pdf

[MINAM] Ministerio del Ambiente del Perú. 2015. Estrategia Nacional de Humedales. Supreme Decree no. 004-2015-MINAM.

Noriega C. 2012. Nueva Cajamarca: Una ciudad andina en la Amazonía. In Lo urbano en el Perú. Perú Hoy series no. 22. 269-290.

Oktarita S, Hergoualc'h K, Anwar S and Verchot LV. 2017. Substantial $\mathrm{N}_{2} \mathrm{O}$ emissions from peat decomposition and $\mathrm{N}$ fertilization in an oil palm plantation exacerbated by hotspots. Environmental Research Letters 12(10).

Padoch C. 1988. Aguaje (Mauritia flexuosa L.f.) in the economy of Iquitos, Peru. In Balick M, ed., The Palm-Tree of Life: Biology, Utilization and Conservation. Advances in Economic Botany V6. New York: Botanical Garden.

Peres C, Thaise E, Schietti J and Levi T. 2016. Dispersal limitation induces long-term biomass collapse in overhunted Amazonian forests. Proceedings of the National Academy of Sciences 113(4):892-7.

Planas A, Chimner R, Hribljan J, Lilleskov E and Fuentealba B. 2020. The effect of water table levels and short-term ditch restoration on mountain peatland carbon cycling in the Cordillera Blanca, Peru. Wetlands Ecology Management 28:51-69.

Pröpper M and Haupts F. 2014. The culturality of ecosystem services. Emphasizing process and transformation. Ecological Economics 108:28-35.

Ramsar. 2018. Lineamientos para inventarios de turberas tropicales a fin de facilitar su designación como sitios Ramsar. Ramsar info brief 9. https:// www.ramsar.org/sites/default/files/documents/ library/bn9_peatland_inventory_s.pdf

Ramsar. 2002. Resolución VIII.17. Lineamientos para la acción mundial sobre las turberas. https://www.ramsar.org/sites/default/files/ documents/pdf/res/key_res_viii_17_s.pdf

Republic of Peru. 2017. Law no. 30670. Ley que declara de necesidad pública e interés nacional la construcción de la carretera IquitosSaramiriza para su interconexión con la costa norte. Lima: RoP. https://busquedas.elperuano. pe/normaslegales/ley-que-declara-denecesidad-publica-e-interes-nacional-la-cley-n-30670-1572534-2/

Republic of Peru. 2016. Law no. 30215. Ley de Mecanismos de Retribución por Servicios Ecosistémicos. Lima: RoP. https://busquedas. elperuano.pe/normaslegales/apruebanreglamento-de-la-ley-n-30215-ley-demecanismos-de-decreto-supremo-n-009-2016minam-1407244-4/

Republic of Peru. 2015. Contribución prevista $y$ determinada a nivel nacional (INDC) de la República del Perú. Lima: RoP. https:// www4.unfccc.int/sites/ndcstaging/ PublishedDocuments/Peru\%20First/ iNDC\%20Per\%C3\%BA\%20castellano.pdf

Republic of Peru. 1997. Law no. 26834. Ley de Areas Naturales Protegidas. Lima: RoP. http:// www.leyes.congreso.gob.pe/Documentos/ Leyes/26834.pdf

Román-Cuesta R, Salinas N, Asbjornsen H, Oliveras I, Huamán V, Gutiérrez Y, Puelles L, Kala J, Yabar D, Rojas M, et al. 2011. Implications of fires on carbon budgets in Andean cloud montane forest: The importance of peat soils and tree resprouting. Forest Ecology and Management 261(11):1987-97.

Ross N. 2002. Lacandon Maya intergenerational change and the erosion of folk biological knowledge. In Stepp JR, Wyndham FS and Zarger R., eds., Ethnobiology and Biocultural Diversity. Athens: International Society of Ethnobiology.

Roucoux K, Lawson I, Baker T, Honorio E, Gosling W and Lahteenoja O. 2013. Vegetation development in an Amazonian peatland. Palaeogeography, Palaeoclimatology, Palaeoecology 374:242-55.

Roucoux K, Lawson I, Baker T, Torres D, Draper FC, Lahteenoja O, Gilmore MP, Honorio E, Kelly TJ, Mitchard ET and Vriesendorp CF. 2017. Threats to intact tropical peatlands and opportunities for their conservation. Conservation Biology 31:1283-92.

Salvador F and Cano A. 2002. Lagunas y oconales: Los humedales del trópico andino. Cuadernos de Biodiversidad 11:4-9.

Salvador F, Monerris J and Rochefort L. 2014. Peatlands of the Peruvian Puna ecoregion: Types, characteristics and disturbance. Mires and Peat 15.

Sánchez M, Chimner R, Hribljan J, Lilleskov E and Suárez E. 2017. Carbon dioxide and methane fluxes in grazed and undisturbed 
mountain peatlands in the Ecuadorian Andes. Mires and Peat 19:1-18. doi:10.19189/ MaP.2017.OMB.277

Saatchi S, Houghton RA, Dos Santos Alvalá R, Soares J and Yu Y. 2007. Distribution of aboveground live biomass in the Amazon basin. Global Change Biology 13:816-37. doi:10.1111/j.1365-2486.2007.01323.x

Schulz C, Martín M, Pérez C, Villacorta M, Laurie N, Lawson I and Roucoux K. 2019. Peatland and wetland ecosystems in Peruvian Amazonia: Indigenous classifications and perspectives. Ecology and Society 24.

[SERNANP] Servicio Nacional de Áreas Naturales Protegidas por el Estado. 2020. Reserva Nacional Pacaya Samiria. Accessed 5 July 2020. https://www.sernanp.gob.pe/aguaje-pacaya

Swindles G, Morris P, Whitney B, Galloway J, Galka M, Gallego-Sala A, Macumber A, Mullan D, Smith M, Amesbury M, et al. 2017. Ecosystem state shifts during long-term development of an Amazonian peatland. Global Change Biology 24:738-57.

Tropical Forest Alliance. 2020. International promotion of Peru's "tree of life" fruit to generate income for indigenous communities and protect Peru's valuable Amazonian forest [press release]. Accessed 10 September 2020. https://www. tropicalforestalliance.org/
Van Lent J, Hergoualc'h K, Verchot L, Oenema O and Van Groenigen J. 2019. Greenhouse gas emissions along a peat swamp forest degradation gradient in the Peruvian Amazon: Soil moisture and palm roots effects. Mitigation and Adaptation Strategies for Global Change 24:625-43.

Verzijl A and Guerrero S. 2013. The system nobody sees: Irrigated wetland management and alpaca herding in the Peruvian Andes. Mountain Research and Development 33(3):280-93.

Wang S, Zhuang Q, Lähteenoja O, Draper F and Cadillo-Quiroz H. 2018. Potential shift from a carbon sink to a source in Amazonian peatlands under a changing climate. Proceedings of the National Academy of Sciences of the United States of America 115:12407-12.

Xu J, Morris P, Liu, J and Holden J. 2018. Peatmap: Refining estimates of global peatland distribution based on a meta-analysis. Catena 160:134-140.

Yu Z, Beilman D, Frolking S, MacDonald G, Roulet N, Camill P and Charman D. 2012. Peatlands and their role in the global carbon cycle. Eos 92(12).

Ziegler G. 2020. Arrasar la tierra: Una comunidad resiste el tráfico de humedales. Ojo Público. Accessed 15 July 2020. https://ojo-publico. com/1946/arrasar-la-tierra-el-trafico-dehumedales-en-sierra-de-lima 

CIFOR Occasional Papers contain research results that are significant to tropical forest issues. This content has been peer reviewed internally and externally.

- Peru is one of the richest peatland countries in the tropics. Its peatlands extend over all three of its regions, with a significant area in the Amazon. These peatlands provide key ecosystem services - storing immense amounts of carbon, uptaking carbon dioxide, nurturing unique biodiversity, regulating water at local and regional levels, and providing both livelihoods and cultural values for local people.

- The country's peatlands have deteriorated through anthropogenic activities, including infrastructure construction and resource extraction (e.g. oil, minerals), and unsustainable uses or practices of varying intensity (e.g. overgrazing, peat extraction, palm felling, overhunting); such practices both threaten them and increase their vulnerability. Climate changes also compromise their stability.

- $\quad$ The Peruvian regulatory framework includes norms and instruments for the sustainable management of wetlands, but peatland-specific regulations are yet to be developed. Recent advances include the elaboration of a national definition for peatlands; however, peatlands are yet to be explicitly included in climate change strategies like REDD+ and NDCs.

- There is a critical lack of scientific research on Peruvian peatlands; they need to be mapped and inventoried, and their ecological properties and economic and social values characterized. If they are to be sustainably managed, it is also essential to identify and value the knowledges and practices of indigenous communities.

- The opportunities for the conservation and good management of these key ecosystems are many, including consolidation of mechanisms of payment for ecosystem services, implementation of sustainable resource management plans by the local population, expansion of protected natural areas, and recognition of communities' tenure rights.

\begin{tabular}{|c|c|c|}
\hline 21/ & $\begin{array}{l}\text { RESEARCH } \\
\text { PROGRAM ON } \\
\text { Forests, Trees and } \\
\text { Aqroforestry }\end{array}$ & $\begin{array}{l}\text { This research was carried out by CIFOR as part of the CGIAR Research Program on Forests, Trees and } \\
\text { Agroforestry (FTA). FTA is the world's largest research for development program to enhance the role } \\
\text { of forests, trees and agroforestry in sustainable development and food security and to address climate } \\
\text { change. CIFOR leads FTA in partnership with Bioversity International, CATIE, CIRAD, INBAR, ICRAF and TBI. }\end{array}$ \\
\hline 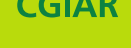 & & FTA's work is supported by the CGIAR Trust Fund: cgiar.org/funders/ \\
\hline
\end{tabular}

